\title{
ANTIMICROBIAL TREATMENT BEFORE DENTAL PROCEDURES IN PATIENTS WITH BACTERIAL ENDOCARDITIS
}

\author{
Adriana Krasteva ${ }^{1}$, Assya Krasteva ${ }^{2}$, Angelina Kisselova ${ }^{2}$ \\ ${ }^{1}$ Department of Pharmacology and Toxicology, Faculty of Pharmacy, \\ ${ }^{2}$ Department of Imaging and Oral Diagnostic, Faculty of Dental Medicine, \\ Medical University, Sofia, Bulgaria
}

\section{ABSTRACT}

Infective endocarditis is a rare condition with significant morbidity and mortality. It may arise following bacteraemia in a patient with a predisposing cardiac lesion. In an attempt to prevent this disease, over the past 50 years, at-risk patients have been given antibiotic prophylaxis before dental procedures.

\section{INTRODUCTION:}

Some of the antibiotics are presented as prophylaxis of infective endocarditis in patients at risk with rheumatic, inherited or acquired heart disease who are undergoing invasive dental procedures. The prophylaxis is of a high importance in order to be reduced the risk of bacteraemia after dental procedures.

Our goal is to present the most commonly used prescriptions in dentistry to be in favor of dental practitioners when choosing the antibiotic prophylaxis for patients at risk.

\section{PRESCRIPTIONS:}

\section{ADULTS} Ospamox)

Rp. Amoxicillin caps. 500 mg (Duomox, Amopen,

D.t.d. 4 caps.

S. 4 caps. $(2$ g) p.o., 1 hour before the dental procedure*

Note: Standart prophylaxis scheme of infective endocarditis in adults and children $>30 \mathrm{~kg}$

\section{ADULTS WHO CANNOT TAKE ORAL MEDICATION \\ Rp. Ampicillin fl. 1000 mg (Ampicillin, Standacillin) \\ D.t.d. $1000 \mathrm{mg}$, diluted 1:4 in sterile saline solution \\ S. 2 g i.m.or i.v. $30 \mathrm{~min}$ before the dental procedure*}

\section{ADULTS ALLERGIC TO PENICILLIN}

Rp. Clindamycin caps. $300 \mathrm{mg}$ (Dalacin C, Clindamycin MIP 300)

D.t.d. 2 caps

S. 2 caps p.o., 1 hour before the dental procedure*

or

Rp. Cefadroxil caps. 500 mg (Biodroxil, Duracef)

D.t.d. 4 caps

S. 2 caps p.o., 1 hour before the dental procedure*

Note: To be avoided in patients allergic to penicillin.

or

Rp. Azithromycin caps. 500 mg (Azatril, Azibiot, Sumamed)

D.t.d. 1 caps

S. 1 caps p.o., 1 hour before the dental procedure*

* Patients with high risk: half of the dose could be repeated 6 hours after the initial dose (exception is azithromycin, where a second dose is not necessary).

ADULTS ALLERGIC TO PENICILLIN AND CANNOT TAKE ORAL MEDICATION Rp.

Cefazolin fl. $1000 \mathrm{mg}$ (Kefzol, Cefazolin)

D.t.d. $1000 \mathrm{mg} \mathrm{fl.}$

S. $1000 \mathrm{mg}$ i.m. or i.v. $30 \mathrm{~min}$ before the dental procedure*

\section{CHILDREN}

Rp. Amoxicillin powder for oral suspension $125 \mathrm{mg} /$

$5 \mathrm{ml}$ or $250 \mathrm{mg} / 5 \mathrm{ml}$ (Amopen, Ospamox)

D.t.d. $60 \mathrm{ml} \mathrm{fl}$.

S. $50 \mathrm{mg} / \mathrm{kg}$ p.o. 1 hour before the dental procedure*

Note: Standart prophylaxis scheme of infective endocarditis in children $>30 \mathrm{~kg}$. The initial dose amoxicillin could be calculated according to patients body weight: $<15$ kg, 750 mg; 15-30 kg, 1000 mg; >30 kg, 2000 mg 
CHILDREN ALLERGIC TO PENICILLIN

Rp. Cefadroxil fl. powder for oral suspension 250 $\mathrm{mg} / 5 \mathrm{ml}$ (Duracef)

D.t.d. $60 \mathrm{ml} \mathrm{fl}$.

S. $50 \mathrm{mg} / \mathrm{kg}$ p.o. 1 hour before the dental procedure

Note: To be avoided in patients allergic to penicillin

or

Rp. Azithromycin fl. powder for oral suspension 100 $\mathrm{mg} / 5 \mathrm{ml}$ or $200 \mathrm{mg} / 5 \mathrm{ml}$ (Sumamed)

D.t.d. $20 \mathrm{ml} \mathrm{fl}$.

S. $15 \mathrm{mg} / \mathrm{kg}$ p.o. 1 hour before the dental procedure

CHILDREN ALLERGIC TO PENICILLIN AND CANNOT TAKE ORAL MEDICATION

Rp. Cefazolin fl. $500 \mathrm{mg}$ (Kefzol)

D.t.d. $500 \mathrm{mg}$ fl.

S. $25 \mathrm{mg} / \mathrm{kg}$ g i.m. or i.v. 1 hour before the dental procedure

\section{PATIENTS WITH HIGH RISK}

Rp. Ampicillin fl. 1000 mg (Ampicillin, Standacillin)

D.t.d. $1000 \mathrm{mg}$ fl., diluted 1:4 in sterile saline solution

S. $2 \mathrm{~g}$ i.m.or i.v. $30 \mathrm{~min}$ before the dental procedure

toghether with

Rp. Gentamycin fl. $40 \mathrm{mg} / \mathrm{ml} ; 80 \mathrm{mg} / 2 \mathrm{ml}$ (Gentamycin)

D.t.d. according to be body weight

S. $1.5 \mathrm{mg} / \mathrm{kg}$ (do not exceed $120 \mathrm{mg}$ ) i.m. or i.v. 30 min before the dental procedure

6 hours later

Ampicillin $1000 \mathrm{mg} / 100 \mathrm{ml}$ i.m.or i.v. or Amoxicillin 1000 mg p.o.

PATIENTS WITH HIGH RISK, ALLERGIC TO AMPICILLIN AND AMOXICILLIN

Rp. Vancomycin fl. 1000 mg (Vancocin)

D.t.d. $1000 \mathrm{mg}$

S. $1000 \mathrm{mg}$ i.v. to be applied for 1-2 hours.

together with

Rp. Gentamycin fl. $40 \mathrm{mg} / \mathrm{ml} ; 80 \mathrm{mg} / 2 \mathrm{ml}$ (Gentamycin)

D.t.d. according to the body weight

S. $1.5 \mathrm{mg} / \mathrm{kg}$ (do not exceed $120 \mathrm{mg}$ ) i.m. or i.v. 30 min before the dental procedure

\section{PATIENTS WITH RISK}

Ospamox)

Rp. Amoxicillin caps. 500 mg (Duomox, Amopen,

D.t.d. 4 caps
S. 2 g p.o. 1 hour before the dental procedure*

together with

Rp. Ampicillin fl. 1000 mg (Ampicillin, Standacillin)

D.t.d. 2 fl. $1000 \mathrm{mg}$

S. 2 g i.m. or i.v. 30 min before the dental procedure*

PATIENTS WITH RISK, ALLERGIC TO AMPICLLIN AND AMOXICILLIN

Rp. Vancomycin fl. $1000 \mathrm{mg}$ (Vancocin)

D.t.d. 1 fl. $1000 \mathrm{mg}$

S. $1 \mathrm{~g}$ to be applied slowly for about 1-2 hours i.v.

$30 \mathrm{~min}$ before the dental procedure*

\section{PATIENTS WITH HIGH RISK - CHILDREN}

Rp. Ampicillin fl. 1000 mg (Ampicillin, Standacillin) D.t.d. 2 fl. $1000 \mathrm{mg}$

S. $50 \mathrm{mg} / \mathrm{kg}$ i.v. or i.m. (do not exceed $120 \mathrm{mg}$ ) 30 min before the dental procedure*

together with

Rp. Gentamycin fl. $40 \mathrm{mg} / \mathrm{ml} ; 80 \mathrm{mg} / 2 \mathrm{ml}$ (Gentamycin)

D.t.d. according to the body weight

S. $1,5 \mathrm{mg} / \mathrm{kg}$ (do not exceed $120 \mathrm{mg}$ ) i.m. or i.v. $30 \mathrm{~min}$ before the dental procedure.

\section{6 hours later}

Ampicillin $25 \mathrm{mg} / \mathrm{kg}$ i.m.or i.v. or Amoxicillin $25 \mathrm{mg} /$ kg p.o.

\section{PATIENTS WITH HIGH RISK - CHILDREN, ALLERGIC TO AMPICILLIN AND AMOXICILLIN}

Rp. Vancomycin fl. $1000 \mathrm{mg}$ (Vancocin)

D.t.d. $1 \mathrm{fl} .1000 \mathrm{mg}$

S. $20 \mathrm{mg} / \mathrm{kg}$ i.v. to be applied for $1-2$ hours.

together with

Rp. Gentamycin fl.40 mg/ml; $80 \mathrm{mg} / 2 \mathrm{ml}$ (Gentamycin)

D.t.d. according to the body weight

S. $1,5 \mathrm{mg} / \mathrm{kg}$ (do not exceed $120 \mathrm{mg}$ ) i.m.or i.v. 30 min before the dental procedure.

\section{PATIENTS WITH RISK - CHILDREN}

Rp. Ampicillin fl. $1000 \mathrm{mg}$ (Ampicillin, Standacillin)

D.t.d. 1 fl. $1000 \mathrm{mg}$

S. $50 \mathrm{mg} / \mathrm{kg}$ i.m. or i.v. $30 \mathrm{~min}$ before the dental procedure. $^{++}$ 


\section{PATIENTS WITH RISK - CHILDREN, ALLERGIC TO AMPICILLIN AND AMOXICILLIN}

Rp. Vancomycin fl. 1000 mg (Vancocin)

D.t.d. $1 \mathrm{fl} .1000 \mathrm{mg}$

S. $20 \mathrm{mg} / \mathrm{kg}$ i.v. to be applied for about $1-2$ hours $30 \mathrm{~min}$ before the dental procedure.

for adults.

${ }^{++}$Total dose for children should not exceed the dose

\section{REFERENCES:}

1. Alice Kim, T. Keys. Infective endocarditis prophylaxis before dental procedures: New guidelines spark controversy. Cleveland Clinic Journal of Medicine 2008; 75: 90-92.

2. Larry Baddour, W. Wilson, A. Bayer, et al. Indective Endocarditis. Circulation
2005;111:394-434.

3. O. Cavezzi Junior. Antimicrobial prophylaxis against infective endocarditis for dental procedure. - A brief commentary. The Internet Journal of Dental Science. 2009; 7

4. Prophylaxis against infective endocarditis. Antimicrobial prophylaxis against infective endocarditis in adults and children undergoing interventional procedures. Nice Clinical guideline 64, Developped by the Center for Clinical Practice at NICE 2008.

Address for correspondence:

Adriana Krasteva

Department of Pharmacology and Toxicology, Faculty of Pharmacy,

Medical University, Sofia, Bulgaria

E-mail: adriakr@gmail.com 